\title{
Strange interlude at Virgohamna, Danskøya, Svalbard, 1906: the merkelig mann, the engineer and the spy
}

\author{
P. J. Capelotti, ${ }^{1}$ Herman Van Dyk $^{2} \&$ Jean-Claude Cailliez ${ }^{3}$ \\ 1 P. J. Capelotti, Division of Social and Behavioral Sciences, Penn State University, USA \\ 27 Birchwood Avenie, Peabody, MA 01960, USA \\ 375 avenue de Mategnin, $\mathrm{CH}-1217$ Meyrin, Switzerland
}

Keywords

North Pole; Wellman; Nansen; Savlbard; Airship; Motor sledge; Zeppelin.

\section{Correspondence}

P. J. Capelotti, Division of Social and Behavioral Sciences, Penn State University, Abington College, Abington, PA 19001, USA. Email: pjc12@psu.edu

doi:10.1111/j.1751-8369.2007.00008.x
Just over a century ago, the American journalist Walter Wellman first tried to reach the North Pole by airship. Despite the hoopla that surrounded the expedition, it was a fiasco and the attempt became a quirky and somewhat obscure episode in the history of polar exploration. In this issue of Polar Research, we present two complementary contributions about this event. The first paper, below, is a collaboration between Penn State University Abington College archaeologist P. J. Capelotti, engineer and airship historian Herman Van Dyk and Swiss aeronautical historian Jean-Claude Cailliez. It presents new data on the initial operations of Wellman's attempt to reach the pole in 1906.

-The editor
Between 1894 and 1909, the American journalist Walter Wellman (Fig. 1) organized and led five expeditions in search of the geographic North Pole (Barr 1980; Capelotti 1999a, 2006; Baldwin 2004). Wellman launched his most ambitious undertaking in 1906, constructing an extensive base camp complete with an airship hangar on the shoreline of Virgohamna, on the island of Danskøya in the Svalbard archipelago, in plain view of the ruins of the balloon shed used a decade earlier by the Swede Salomon August Andrée during his polar balloon expeditions (Barr 1980; Capelotti 1994, 1997, 1999b; see map in Diesen \& Fulton 2007).

This paper examines three previously unexplored aspects of the operations at Wellman's 1906 base camp. First, we examine the design and construction of a polar motor sledge planned as an emergency vehicle in case the airship crashed on the polar ice pack. Second, we look at the design and construction by the Swiss engineer Alexandre Liwentaal of the great hangar necessary to shelter the airship while it was being assembled, inflated and readied for its polar flights. Lastly, the interests in Wellman's aeronautical explorations by an expansionist German Empire are noted.

\section{Wellman returns to Svalbard, 1906}

In late 1905, Wellman convinced Victor F. Lawson, owner of The Chicago Record-Herald, to pledge $\$ 75000$ toward the construction of an airship similar to the Frenchdesigned Lebaudy. This new airship would be capable of carrying a small band of explorers to the as yet undiscovered North Pole. By March 1906, Wellman had subscribed the support of the National Geographic Society, the French Academy of Science, and even President Theodore Roosevelt himself. Eventually, Wellman raised a quarter of a million dollars.

This monumental sum enabled the construction in Paris of a polar airship and, on the remote island of Danskøya in north-west Svalbard, barely $1000 \mathrm{~km}$ from the North Pole, of a large hangar and expedition base camp (see map in Diesen \& Fulton 2007). Why Wellman chose Virgohamna for his airship base camp is not clear. He had visited Svalbard once before, when he first attempted to reach the North Pole in 1894. This sledge expedition was halted when its support ship, the Ragnvald Jarl, was nipped and sunk by ice along the shores of Waldenøya. During this expedition, Wellman had stopped to use the house owned by the British hunter, Arnold Pike, at Virgohamna (see Capelotti 1997: 11). Wellman later claimed that he had formed the idea of using an aerial machine to reach the pole even before Salomon Andrée (Wellman 1911: 35-39). Whatever the truth of this claim, Wellman sought in vain to locate the lost Andrée during his 1898-99 Franz Josef Land expedition. As a journalist, he was most certainly aware of the publicity that would attach to any such discovery (for 


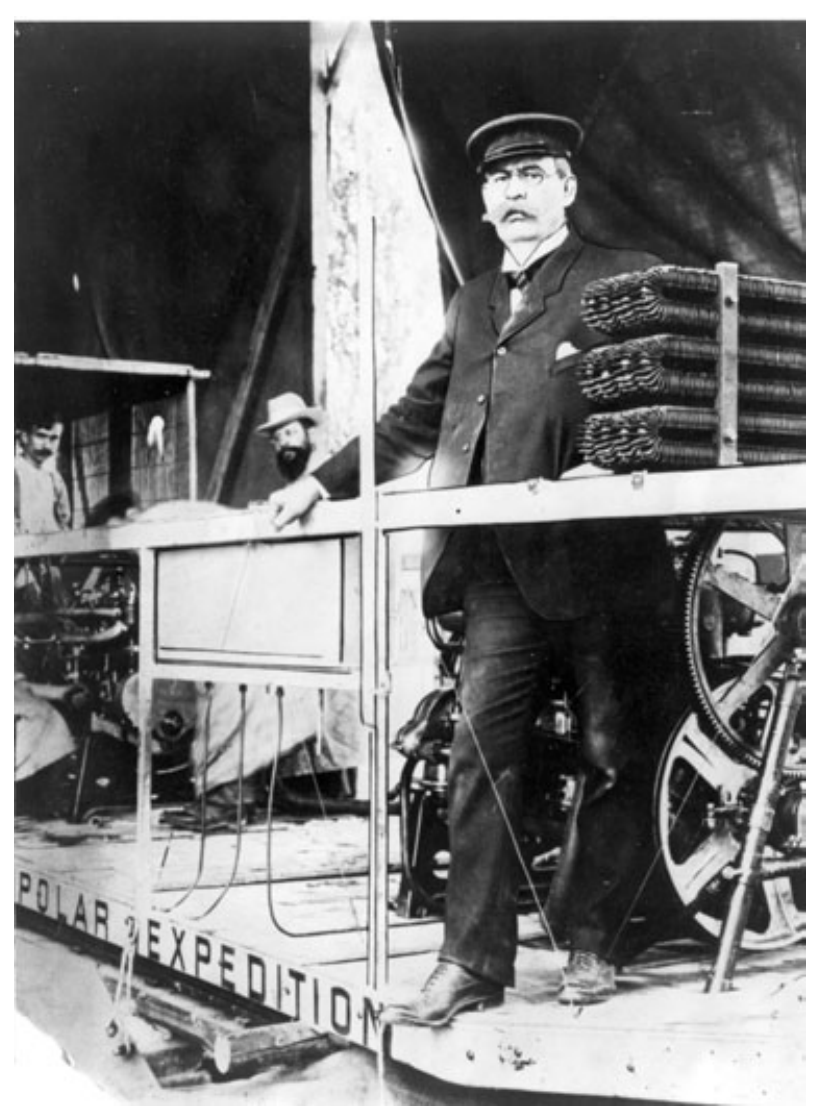

Figure 1 Walter Wellman in Kristiania (Oslo) in the late spring of 1906. He is standing in the deck of the 1906 Godard-designed and -built polar airship. (Courtesy of Library of Congress.)

example, see Wellman 1898; Baldwin 2004: 9-10). So it is logical that he would seek to use Virgohamna for the existing infrastructure (Pike's House), for whatever supplies the Andrée expedition had left behind and for the notoriety of the site on account of its associations with the Andrée mystery.

At the National Geographic Society, the motion to support Wellman's 1906 polar expedition was moved by the inventor Alexander Graham Bell-after whom Wellman had named an island in Franz Josef Land in 1899 (see Capelotti 2006). The Society appointed a Major Henry E. Hersey to lead a scientific party. Like Evelyn Briggs Baldwin, Wellman's second-in-command on the Franz Josef Land expedition, Hersey, was a meteorologist for the US Weather Bureau. He became the construction supervisor for the Virgohamna base camp.

Wellman's airship was designed and constructed in Paris late in the spring of 1906 by the firm of Louis Godard. Parisian engineers had given Wellman conflicting advice on what type of airship possessed the best chance to reach the North Pole. One faction argued for a fast airship that could make a quick trip to the pole without touching the earth. The other faction, whom Wellman described as the ones who advocated "safety and sanity", argued for an airship with a trailing ballast tube filled with reserve provisions (New York Times, 11 March 1906). Through its trailing ballast tube, called an equilibrator, this airship would keep in constant touch with the Earth, at an altitude between 33 and $100 \mathrm{~m}$, depending on factors like changing atmospheric conditions, the amount of hydrogen gas used and the amount of petrol and other supplies consumed.

Even though Wellman had analysed Fridtjof Nansen's data on wind speeds over the polar ocean and concluded that in the months of July and August there would be on average only 5 hours out of every 10 days when the airship would confront winds of more than 17 miles (27 km) per hour (Wellman 1911: 161-162), Wellman sided with the "safety and sanity" school. In retrospect, Wellman should have paid more attention to his analysis that showed that the airship would face winds of less than $11.2 \mathrm{~km}$ per hour nearly $50 \%$ of the time. A fast airship, even in 1906, could have reached the pole and returned to Virgohamna in less than 2 days. By choosing slow safety over rapid risk, Wellman spiked his own dream of an airship that could reach the North Pole and return in one swift, thrilling round-trip expedition.

At the same time as these decisions were being made, a strange motor sledge was also being designed and built in Paris. Wellman announced his various intentions to use motor sledges in his programme when he returned to New York from pre-expedition meetings in Europe in March 1906. In the New York Times (11 March 1906), Wellman expressed the idea that he might land and collect scientific data on the polar ice cap at places other than the North Pole. For this purpose, as well as to return back to his base camp from a potential forced landing of the airship, the exploring party would have "four motor sleds which weigh 210 pounds [95.25 kg] each". Just 2 weeks later, these four sledges were reduced to two in a speech to the New York Motor Club on 23 March 1906. In this speech, he admitted that the slow Godard airship would not carry enough fuel to allow him to make a return trip after reaching the pole. Wellman said that he had solved this problem by the expedient of commissioning the construction of two motor sledges, one in Europe and one in the USA, each weighing 210-215 lbs (95.25-97.52 kg). They would be equipped with small engines and carry two persons each. If his tests were successful, Wellman expected to take the two motor sledges on board the airship with him.

As for the new airship, it ultimately proved a total failure. The engines could not be made to perform properly, and the expedition was promptly cancelled in August 1906. The hangar was secured for the winter and a party of three men left in charge. In Wellman's view, he 
had just launched "the first effort to put aerial navigation to actual use in the performance of valuable scientific work" (Wellman 1911: 14).

Others disagreed. In the view of Fridtjof Nansen, Wellman had merely created at Virgohamna a "common looting place for tourists and others looking for souvenirs" (Nansen 1920: 144; translations from En ferd til Spitsbergen were made by Bjarne Petterson in 1994). By the 1990s, possibly due to Nansen's dismissal of Wellman as "this great humbug" (Nansen 1920: 145), Wellman's daring expeditions had been largely forgotten in Norway.

\section{The merkelig mann: Wellman's Arctic motor sledge}

In The aerial age (1911), Wellman wrote not of the sledges weighing $210-215 \mathrm{lb} \quad(95.25-97.52 \mathrm{~kg})$ that he had described to the New York Times and New York Motor Club in March 1906, but of "a light vehicle, weighing only 150 or 200 pounds [68-91 kg] [which] two men could easily lift ... over the hummocks and ridges" of the polar ice pack (Wellman 1911: 120). This lightweight motor sledge would "be used, not to carry loads, but to pull them. It was to be a little locomotive, drawing its string of lightlyloaded sledges behind it" (Wellman 1911: 120). It is not known who built Wellman's motor sledge in France. According to Wellman, his theory was sabotaged by incompetent workers he identifies only as "assistants":

I was compelled to go to America and to leave the details in the hands of assistants. They built the sledges far too heavy-good for work on smooth ice, as they proved when tested out on the lakes of Norway, but useless upon the rough ice of the polar ocean. (Wellman 1911: 133)

The earliest depiction of Wellman's motor sledge can be seen in an illustration of his airship, made before the airship was actually built (Fig. 2). It shows two motor sledges on top of the framework of the car, immediately in front of, and behind, the crew compartment. The annotations on this drawing are all in English, which suggests that the illustration was drawn in the USA. However, this does not necessarily mean that the picture shows the American-designed version of the motor sledge. Although the image is only a few millimeters long, it clearly shows that the design concept is similar to that of a photograph of the sledge constructed in France. The main difference is that the drawing shows one seat, perhaps for two people sitting side by side, while the actual sledge as constructed in France had tandem seating. Also, steering seems to have been accomplished by a bicycle-type handle-bar, rather than a steering wheel. The drawing seems to show a backrest as well as armrests; the actual sledges as constructed appear not to have been that comfortable.

No drawing of the American version of Wellman's planned motor sledge has survived, so it is unknown if it was ever built. But three photographs have been uncovered of the French version. The first, a fuzzy side-view that appeared in Wellman's newspaper, The Chicago Record-Herald, was used by Van Dyk in 1997 to make a design drawing of the likely components of the motorsledge (Fig. 3). A second photograph, also a side view, was found by Capelotti in the archives of the Norwegian Museum of Cultural History in Oslo (Fig. 4). It shows the motor sledge in a state of assembly. The only new detail revealed by this image was that both seats were provided with a cushion or pillow.

In the spring of 2006, the Svalbard guide Andreas Umbreit located a new and oblique view of this same vehicle (Fig. 5). This photograph, taken by Mons. M. Branger in Paris in 1906, filled in most of the missing details of design and construction, allowing a complete detailed drawing to be made (Fig. 6) which served as a basis for the construction of a scale model. The overall length of the motor sledge was $3.3 \mathrm{~m}$ and the width was $1.4 \mathrm{~m}$. The diameter of the drive wheel was $1 \mathrm{~m}$, and its width was $40 \mathrm{~cm}$.

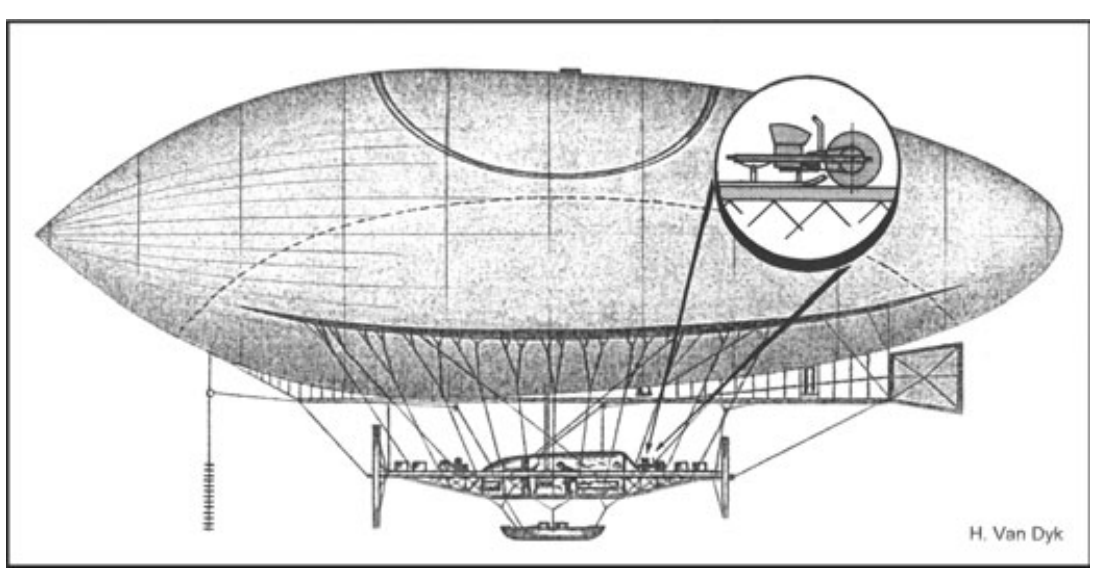

Figure 2 Drawing of the 1906 airship showing two motor sledges mounted on top of the airship car, with a detail of the motor sledge. (Drawing by Van Dyk, after Popular Mechanics 1906: 701-703.) 
Figure 3 Design drawing of the 1906 motor sledge, reconstructed by Van Dyk from a photograph published in The Chicago Record-Herald, 30 June 1906. (1) Manouevring handle; (2) storage area; (3) rear seat; (4) fuel tank; (5) front seat; (6) engine; (7) oil tank; (8) filter; (9) steering wheel; (10) cleats; (11) sprocket wheel; (12) pillow block; (13) drive wheel; (14) roller chain; (15) gear box; (16) flywheel; (17) frame; (18) pivot; (19) suspension spring; (20) runner.
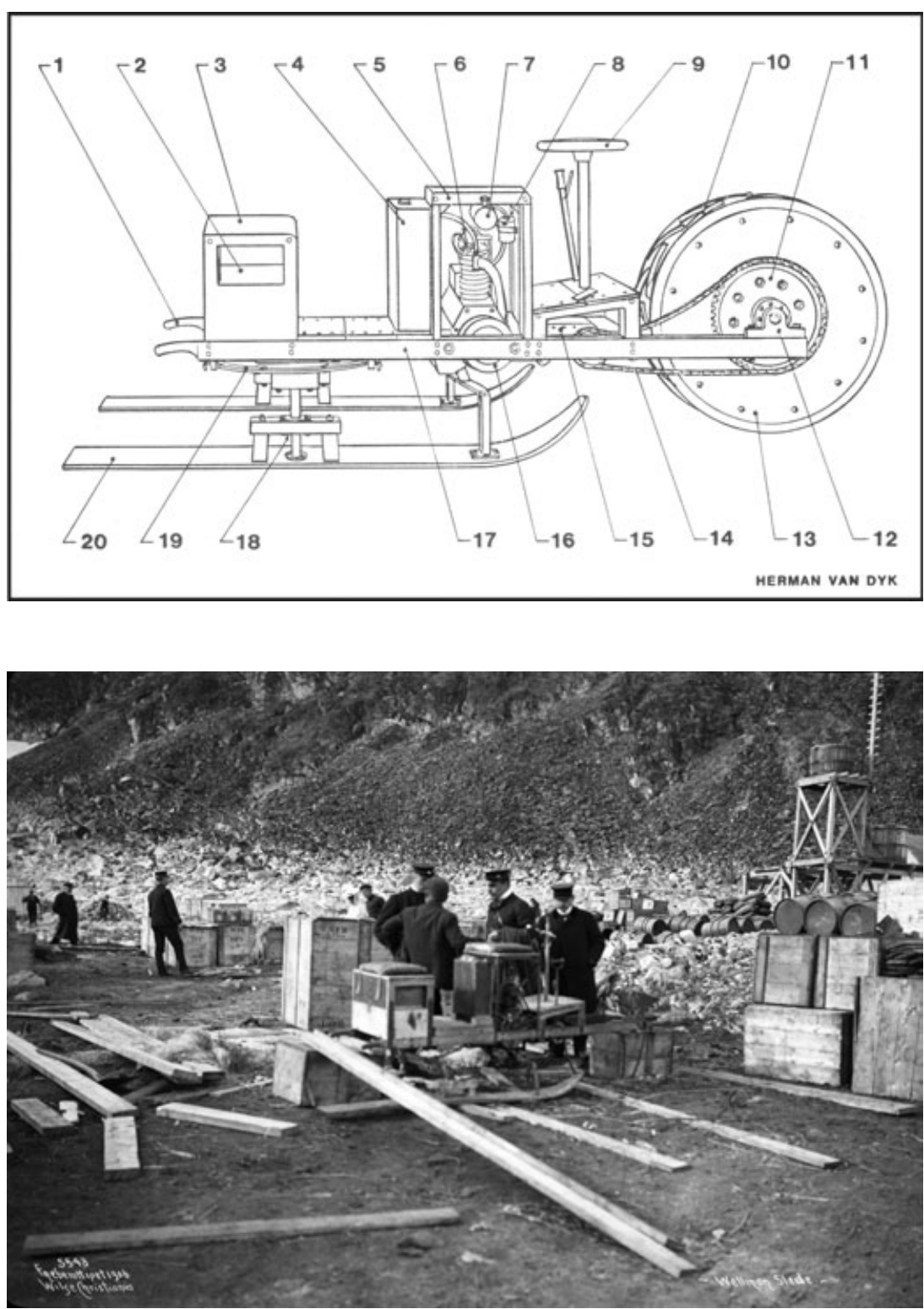

Figure 4 The 1906 motor sledge at Virgohamna, 1906. (Courtesy Norwegian Museum of Cultural History [Norsk Folkemuseum].)

The motor sledge consisted of an $\mathrm{H}$-shaped wooden frame which carried all components, including the engine, two seats, fuel and oil tanks, and storage space. The two longitudinal main beams were supported at the front by a single drive wheel and in the centre by a pair of skis or runners. Both ends of each main beam were shaped into handles, so that four strong individuals could carry the sledge onto, or from, the airship car. For traction on snow and ice, there were two rows of 12 ridges, consisting of short pieces of angle iron, bolted in a Vpattern to the rolling surface of the drive wheel. In between the ridges were four rows of 12 spikes. The frame of the driver's seat was a simple rectangular structure attached to the two main beams. The actual sitting surface consisted of two wooden boards. In front of the driver were the steering wheel and engine controls. The floorboards of the front seat were slightly raised to accommodate the control and drive mechanisms. The driver's seat was located in the middle of the frame and, behind that, was the fuel tank, mounted against the back of the driver's seat. The space underneath the passenger's seat was used for storage. Located between the main beams and below the driver's seat was the engine and, in front of it, the transmission box with sprocket gear for the chain to the drive wheel. A flywheel was mounted on the right end of the crankshaft. The oil tank was directly below the driver's seat. An exhaust tube led from the left side of the engine down and to the rear of the sledge to a 


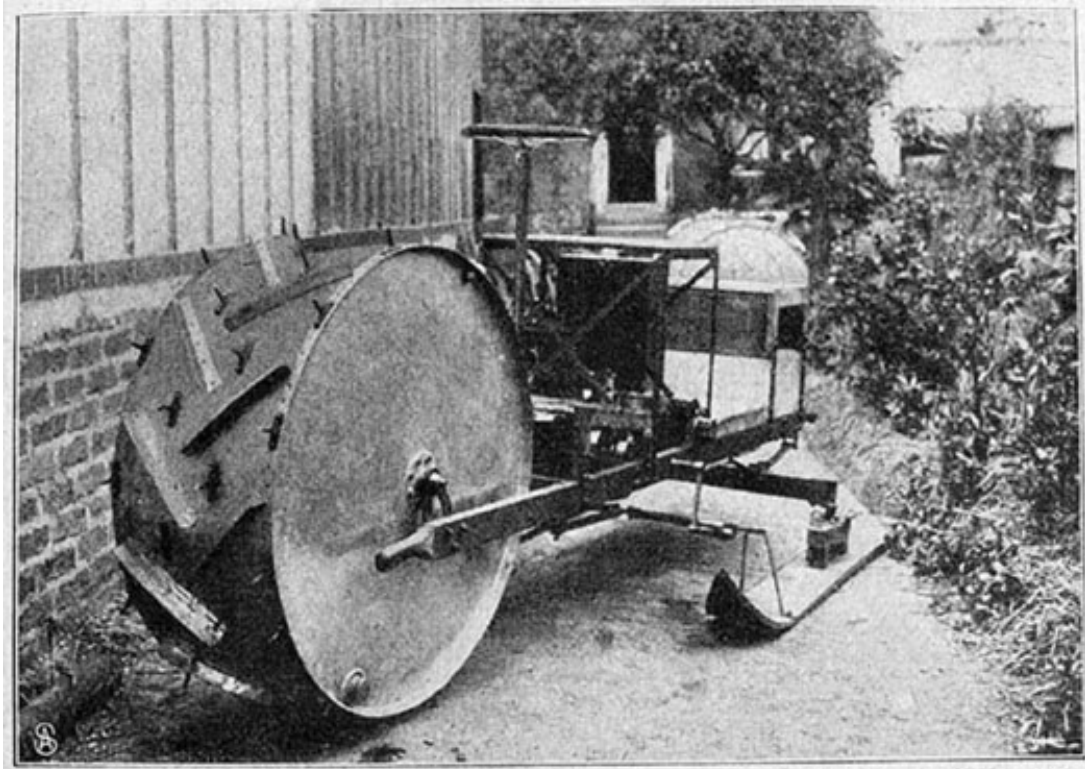

פ. Brangur, \$aris, bhot.

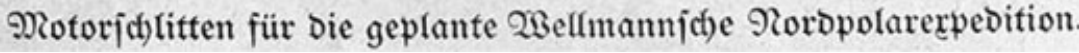

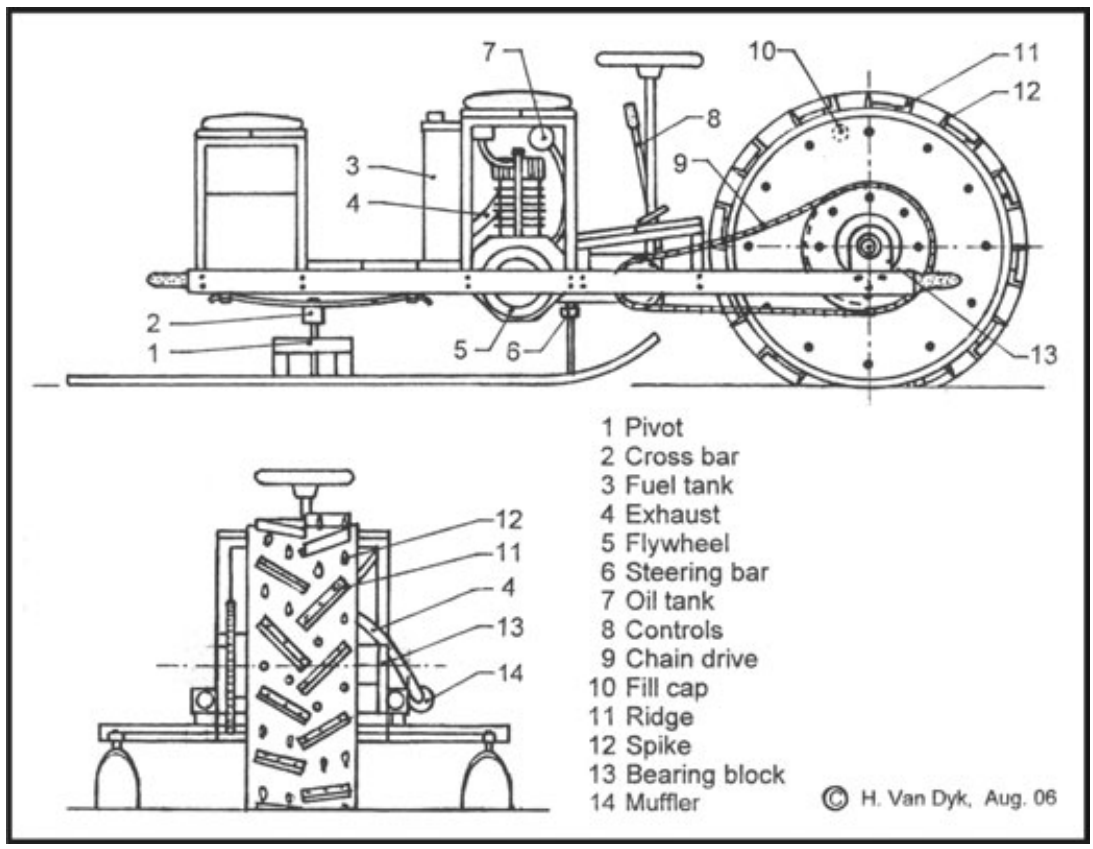

Figure 5 Photograph of the 1906 motor sledge, uncovered by Andreas Umbreit. (Courtesy of Andreas Umbreit.)
Figure 6 New design drawing of the 1906 motor sledge, reconstructed by Van Dyk from the photograph uncovered by Andreas Umbreit. muffler. By sitting sideways, the passenger might have been able to warm his cold feet on it. A crossbar, extending to the left and right, was mounted, via a set of suspension springs, to the main beams. At each end, it formed a pivot holding the skis, which were connected by a linkage to the steering wheel. The photographs show some type of a fitting on the left side of the drive wheel. It could have been a means to fill the drive wheel with water to add weight and improve traction. Surrounded by snow and ice, it would have been a near-impossible task.

The design of the motor sledges was not efficient and Wellman discarded the idea of using them on his airships of 1907 and 1909. The force required to move an object over a surface depends on its weight (mass), the friction coefficient between the object and the surface it is resting on, and the speed. Once an object is in motion, it requires 
only a very small side force to make it move in a different direction. Modern snowmobiles have the weight of the engine, passengers, fuel, etc., resting on a drive belt (wheel) to maximize traction. Only a little weight is on the skis, to facilitate steering. Wellman's sledge, however, had most of the weight resting on the skis, which was to be used for steering, and only a little weight on the drive wheel which was to provide traction.

To Nansen, Wellman was an "odd man" (merkelig mann) whose airship expeditions were essentially advertising schemes that demonstrated how the attention of the world's press could be held, year after year, despite there being nothing of value to report (1920: 145; see Diesen \& Fulton 2007). Nansen reserved special scorn for Wellman's idea to design, build and employ motor sledges on his planned 1906 airship expedition, as well as the notion of using a trailing ballast tube-the "equilibrator"-to stabilize the airship and hold several hundred pounds of reserve supplies.

In his book, En ferd til Spitsbergen (A journey to Spitsbergen; 1920), Nansen derided the idea of the equilibrator as a trailing "sausage" and the motor sledges as the work of a fool who had not thought through how he would fuel them on the return journey from the pole:

The lower part of the sausage should be dragged along the ice. It was possible pieces of it would fall off, especially when some of them got jammed into the pack ice. But these pieces would then be left where they fell and would serve to mark the way where they had travelled. If the airship, for one or another reason, should go down, then those daring travellers, when they came driving back on the motor sledges they did not have yet, could easily find their way back by following these sausage-like pieces. And besides, they could live off off their contents. One important thing was missing, though. They didn't have any gasoline to keep their engines going. (Nansen 1920: 142)

Nansen's critique notwithstanding, Wellman was the first explorer to bring an overland (or over-ice) motor transport machine into the polar regions. A Norwegian Museum of Cultural History photograph (Fig. 4) shows the motor sledge, minus its enormous drive wheel, sitting on the shoreline of Virgohamna in the summer of 1906 as the airship hangar is being constructed. Since Wellman only writes of testing the sledge on a lake in Norway (perhaps Lake Mjøsa, in southern Norway, where Robert Falcon Scott would later test his Antarctic sledges (see the fascinating description of this testing in Diesen $\&$ Fulton 2007), the Folkemuseet image is the only evidence that his motor sledge was actually transported to Virgohamna in anticipation of the polar expedition of 1906. Other polar explorers, like Scott, would not begin to consider the possibilities of polar travel with motor sledges until the fall of 1906 (Fiennes 2003). It is not known if Wellman ever attempted to use his motor sledge at Virgohamna, but given the uneven and rocky terrain, this seems unlikely.

\section{The engineer: Liwentaal's polar airship hangar}

Soon after the completion of the airship and motor sledge in Paris, Wellman sent Major Hersey north to establish a base camp in north-western Spitsbergen, on the shores of Virgohamna on Danskøya (Fig. 7). For a week, Hersey blasted away at the rock and ice at Virgohamna until he had cleared an area nearly the size of an American

Figure 7 The hangar and airship under construction, Virgohamna, 1906. The person standing in front of the propeller blade is most likely Walter Wellman. (Courtesy Norwegian Museum of Cultural History [Norsk Folkemuseum].)

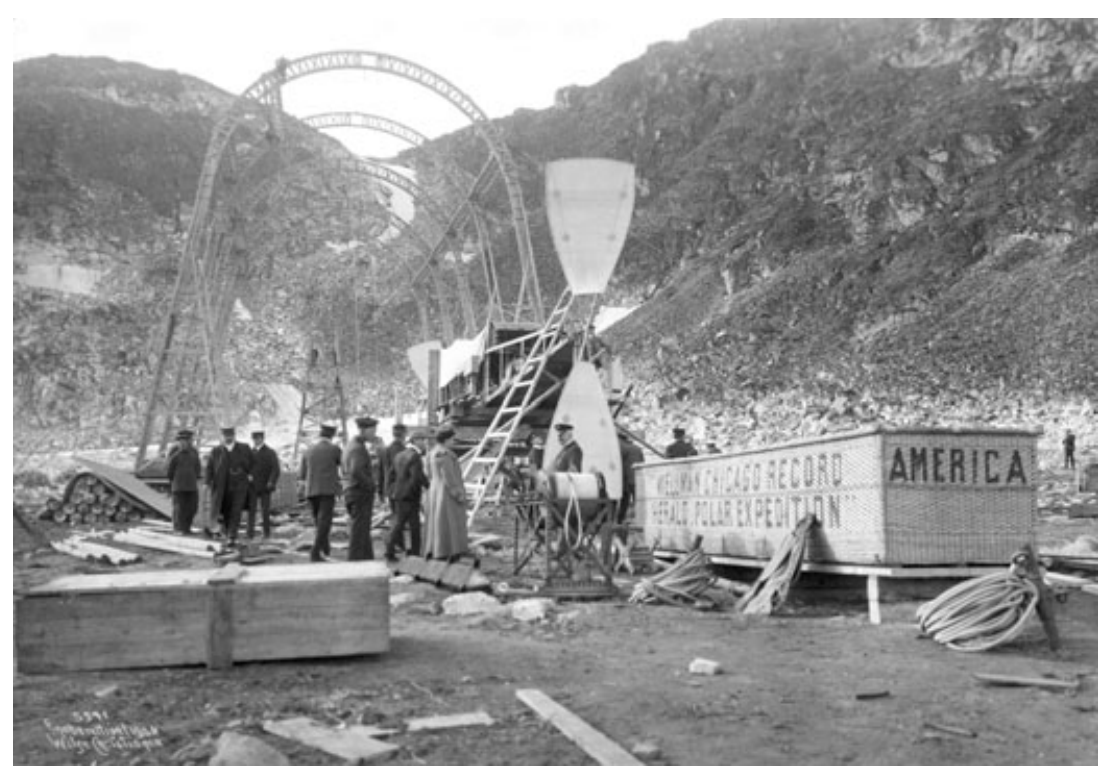


football field for the floor of the airship hangar. The Virgohamna site was adjacent to the remains of the abandoned balloon shed from which Andrée attempted to fly to the pole in 1897. For the floor of Wellman's hangar, Hersey made use of the timbers surviving from Andrée site. "Thus again", wrote Wellman, "was the site of Andree's ill-fated enterprise to be the scene of strange activity" (Wellman 1911: 146).

Hersey brought with him not only "three or four hundred tons [272 155-362 $874 \mathrm{~kg}$ ] of timber and iron" for the hangar and ancillary buildings, but 125 tons (113398 kg) of sulphuric acid and 75 tons (63 $503 \mathrm{~kg}$ ) of scrap iron filings, which, when combined by 30 tons (27 $216 \mathrm{~kg})$ of "apparatus and other chemicals", produced hydrogen for the airship (Wellman 1907: 199). In addition to this enormous load, which required three round trips to and from Tromsø by the Frithjof, Camp Wellman was outfitted with "half a ship-load of provisions; the aeronautic machine and all its appurtenances: dogsledges, motor-sledges, a steam boiler and engine, tons of gasoline, tools, coal, iron rods, bolts, nails, steel boats, and all the paraphernalia of what a London periodical aptly termed 'Mr. Wellman's scientific village in the Arctics' " (Wellman 1911: 154). There was also a forge for molding the iron rods that would stay the wooden arches of the hangar.

Other structures included a machine shop with lathes, drills, and other machine tools; the boiler house, steam engine, steam pump; and, finally, the building containing the gas apparatus to inflate the airship. The main building, which served as Wellman's headquarters, housed 40 scientific staff, engineers, aeronauts, mechanics, sailors and workmen. One of these was the Swiss engineer Alexandre Liwentaal, the man responsible for building the airship hangar. Since Hersey was a meteorologist, it is very likely that the supervision of the hangar construction was left to Liwentaal, whom Wellman described in The aerial age as both an architect and an engineer (1911: $131,153)$ and, in a 1906 article, as someone who had been "associated with Count Zeppelin in the famous airship experiments in Germany and Switzerland" (New York Times, 24 April 1906).

When Wellman arrived on Danskøya, several weeks behind Major Hersey and full of expectation at the thought of steaming into the harbor and seeing the huge hangar, he was greeted instead by only the splintered remains of Andrée's balloon shed. Wellman had budgeted $\$ 10000$ for construction of the hangar (New York Times, 11 March 1906), and was perturbed that it was not further along than he felt it should be. "Our force of men worked hard all summer, but were unable to finish the balloon house and the other buildings in time to make it possible to inflate the airship and get it ready for a voyage.
The engineer Liwentaal had undertaken to complete the balloon house within three weeks after reaching our base. It was all he could do to finish it in nine weeks" (Wellman 1911: 153). Liwentaal's own notes show that he finished the hangar in 6 weeks, but only after Wellman intervened in its construction.

Liwentaal (Fig. 8) had worked for several balloon and airship designers around the turn of the century before signing on with the Wellman Polar Expedition in 1906. He worked in Paris for Lachambre, the builder of Andrée's balloon, from 1895 to 1898, for the Lebaudy airship works in 1903, and did two stints with Count Ferdinand von Zeppelin (1899-1900; 1904-05). Rather than construct a hydrogen generator plant at Virgohamna, Liwentaal had attempted to purchase hydrogen in cylinders from Zeppelin, but Germany had put the strategic material under an export embargo.

Under Liwentaal's supervision, on 13 July 1906, a team of 25 Norwegian workers hired from Trondheim, Tromsø and Hammerfest began to lay the foundation and put down the floor of the hangar. This crew included Paul Bjørvig and Olaf Ellefsen, who had been members of the

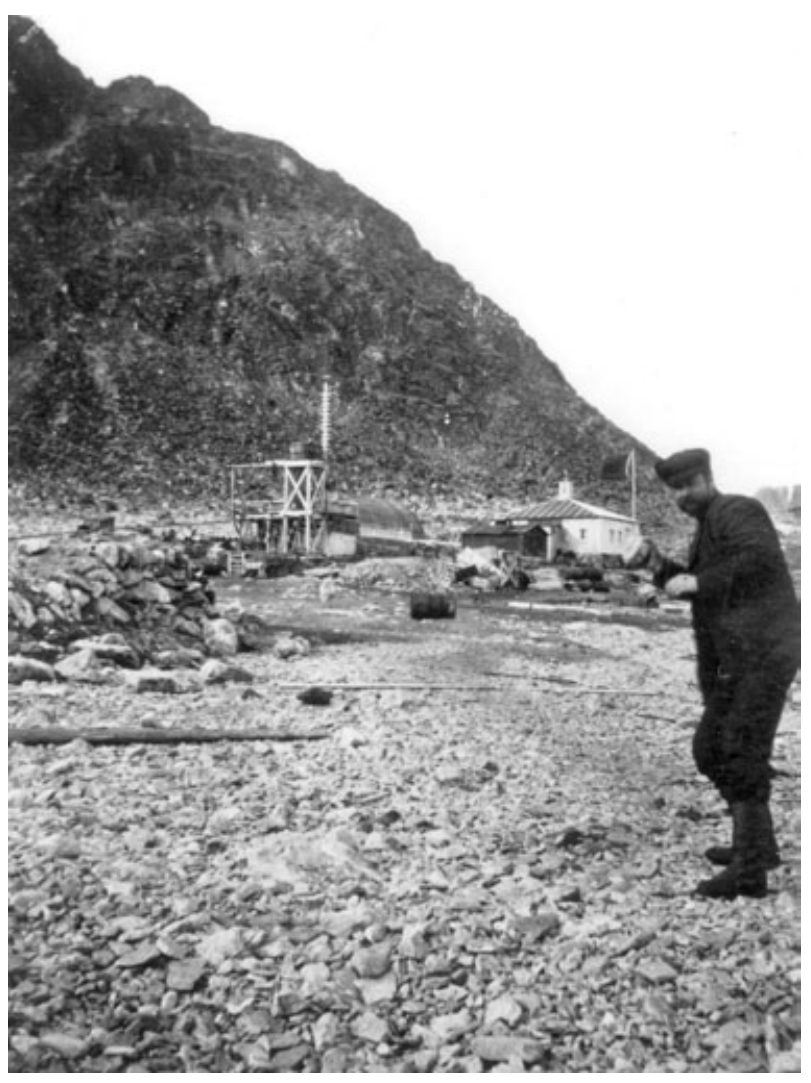

Figure 8 Camp Wellman, Virgohamna, 1906. Cailliez identifies the man as the Swiss engineer Alexandre Liwentaal. (Courtesy Norwegian Polar Institute.) 


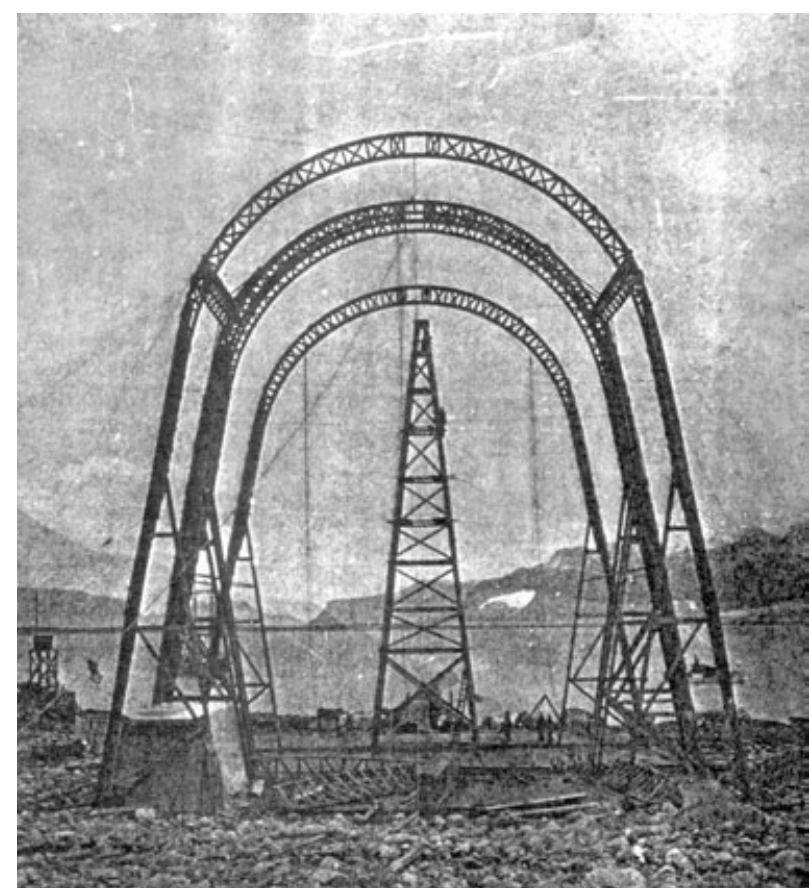

Figure 9 The Liwentaal airship hangar under construction at Virgohamna in 1906. The graceful arches and intersecting diamond supports were constructed by forming green heart around bending frames. These frames could still be seen during an archaeological survey of Virgohamna in 1993. (From Cailliez 2004.)

1898-99 Wellman expedition to Franz Josef Land (see Baldwin 2004). The structure was not completed until 28 August, and then only because Wellman ordered Liwentaal to reduce the number of supporting eight-story-high arches from nine to five (Fig. 9). As Liwentaal explained:

The problem was both difficult and very interesting.

We were to build, on the borders of the polar icebarrier, a complete aeronautical building site, including the hangar of the airship whose dimensions were: length: $58 \mathrm{~m}$; height: $26 \mathrm{~m}$; width at base: $25 \mathrm{~m}$. As the Boreal summer is very short, lasting hardly two months, it was necessary to build the structure quickly. In addition, navigation in the ice-barrier can only be done by a few specialized ships, of small tonnage, whose carrying capacity is further decreased by the ship's hull being one metre thick. It was impossible to place on board any wood that was more than $4 \mathrm{~m}$ in length, nor to load more than $40 \mathrm{~m}^{3}$ on board.

It was thus necessary to design the hangar in order to build with the most reduced minimum of supplies and to organize the construction work at a rate compatible with the voyages of the ship. These data determined the type of hangar, which was considered an elegant solution of the problem, and so construction was begun on 13 July 1906 and was finished on 28 August of the same year. The characteristic of our method is to employ green heart [a dense wood used in European wharf construction], which was very advantageous, to bind it place by means of hoists, then to bolt and brace these sections to preserve the form given to him. The advantages that resulted from this process were: great facility of work, speed of construction, great saving in materials, and the maximum strength against wind resistance. (Cailliez 2004: 108-109; translated by the authors)

As chief engineer for the hangar construction, Liwentaal joined together his control of the art of wood-working with his mathematical skill. His competence was put to the test to create a hangar nearly $30 \mathrm{~m}$ high, which could hold back several years of blizzards and high winds. Despite his impatience with the delays, Wellman recognized the difficulty of this work.

This balloon house was no small job. It had to be built of arches fashioned on the spot, bent and bolted together on bending frames. As fast as the arches were finished they were raised by means of a huge pyramid or derrick manned by a score of men. When the arches were all up they were moved to their proper places and bridges or spans thrown across to bind them together. The whole was covered with nearly an acre of strong canvas prepared in Norway for the purpose. The structure was 210 feet [ $64 \mathrm{~m}$ ] long, 85 feet [ $26 \mathrm{~m}$ ] wide and 85 feet high. The floor was completely covered with boards. (Wellman 1911: 153-154)

Wellman noted that the hangar would never have been finished in the summer of 1906 if he had not taken the step of reducing the arches from nine to five (Fig. 10). This no doubt led to the damage the structure suffered in a July storm in 1907. The hangar was rebuilt, collapsed again in the winter of 1908-09, was rebuilt a third time (Fig. 11) and survived three more winters until collapsing finally in 1912. It survives today as easily the largest and most complete archaeological remnant at Virgohamna (Fig. 12), and was surveyed by Capelotti in 1993.

The remains of the hangar are located to the south-east of the base camp's machinery spaces, and are surrounded by at least 48 rock piles and guy stakes that anchored guy wires that once supported the structure. The $1912 \mathrm{col}-$ lapse created a twisted and chaotic assemblage of foundation beams, deck planks, and arch beams and wires. In several places, especially toward the rear of the hangar, sections of the original deck planks can be seen, and evidence of a limited amount of charring from fires is apparent. The rearward beams are the most intact, with the beams progressively more deteriorated as one moves toward the front of the hangar. It appears that when the hangar collapsed in 1912, it fell from back to front, or 

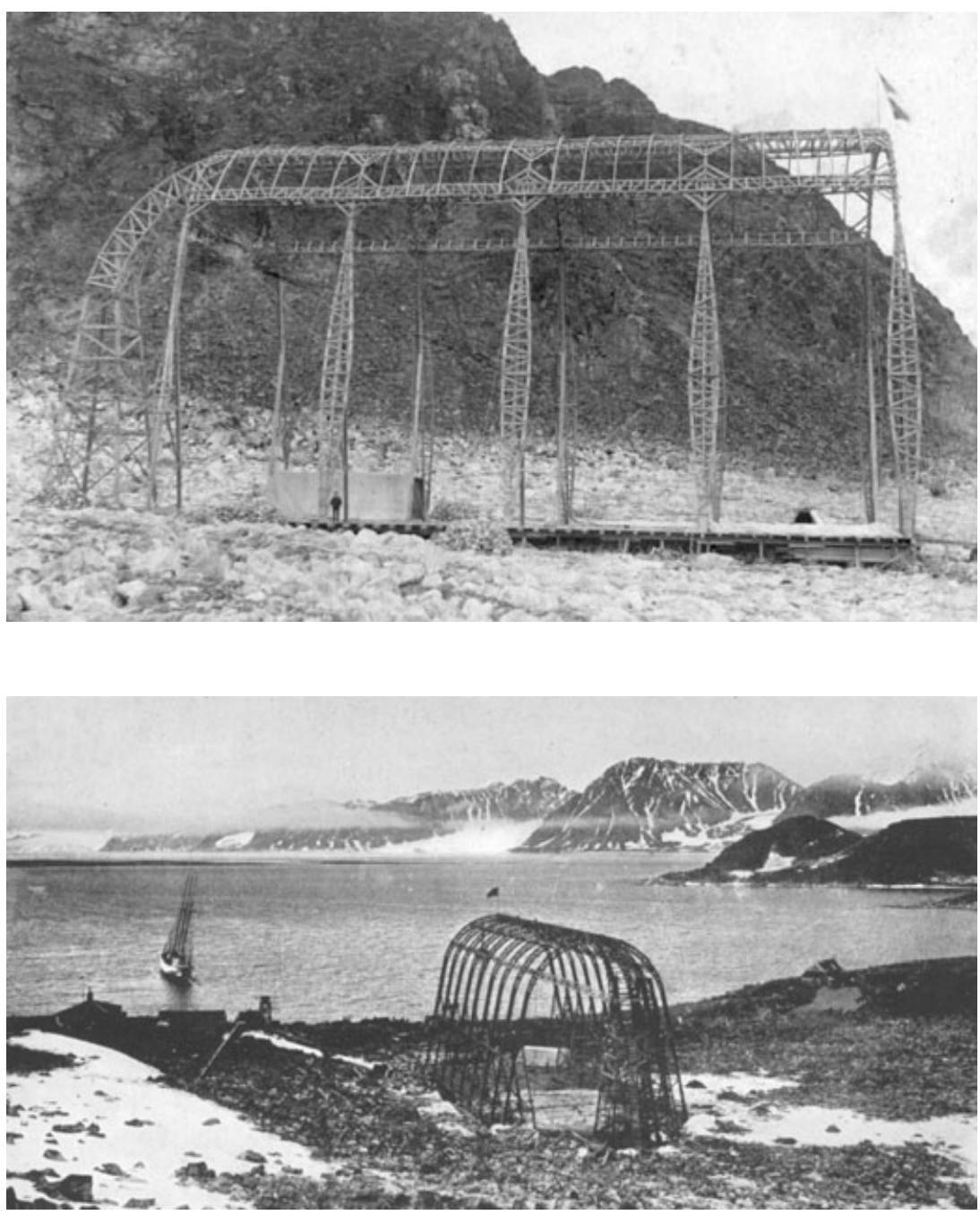

Figure 10 The Liwentaal airship hangar at Virgohamna in 1906. (Note for scale the man standing next to the second arch from the left.) Repairs to this structure delayed the first flight of an airship in the polar regions until 2 September 1907. (From Cailliez 2004.)
Figure 11 The hangar, rebuilt for the 1909 expedition with nine supporting arches, and without the diamond-shaped supports made by Liwentaal in 1906. (From Wellman 1911.) south to north, since the forward-most of the nine arches now lies nearly $35 \mathrm{~m}$ from the front of the hangar itself. From the ridges that surround the site on the east, west and south-west, the outline of the hangar appears much more clearly than it does on the ground, where the weathered grey wood seems to blend in with the surrounding grey shoreline rock. Piles of deck planking were observed at the rear of the hangar, suggesting that systematic removal of parts of the hangar has taken place at some point or points after Wellman abandoned it. For example, George Binney's Oxford University Arctic Expedition in 1921 salvaged wood from Wellman's hangar to build a seaplane slipway at Liefdefjorden (Binney 1925: 70).

Wellman's own measurements of this structure placed it at $24.994 \mathrm{~m}$ (82 feet) wide and $57.912 \mathrm{~m}$ (190 feet) long. Measurements in 1993 differed slightly from this: the width of the hangar ruins is $28.042 \mathrm{~m}$ (92 feet), and the length is $56.998 \mathrm{~m}$ (187 feet). The freshwater spring that Wellman had diverted around the western side of the hangar to the machinery and boiler areas has resumed its course directly under the hangar, with the inevitable rotting and disintegration of the foundation beams, especially at the north-east corner of the hangar, which rests above the same boggy area near to where the remains of the 1906 airship car are located.

\section{The spy: Captain Von Gottberg drinks too much whisky}

Neil Fulton and Jan Anders Diesen recently discovered a short silent motion picture film that includes scenes of the Wellman expedition at Virgohamna (Diesen \& Fulton 2007).Wellman is seen paying homage at the monument to Salomon A. Andrée, and doffing his cap to the camera as he leaves on a small boat to board what is likely the German steamer Express under the command of "Captain Theodore Lerner, a well-known Arctic traveler and 


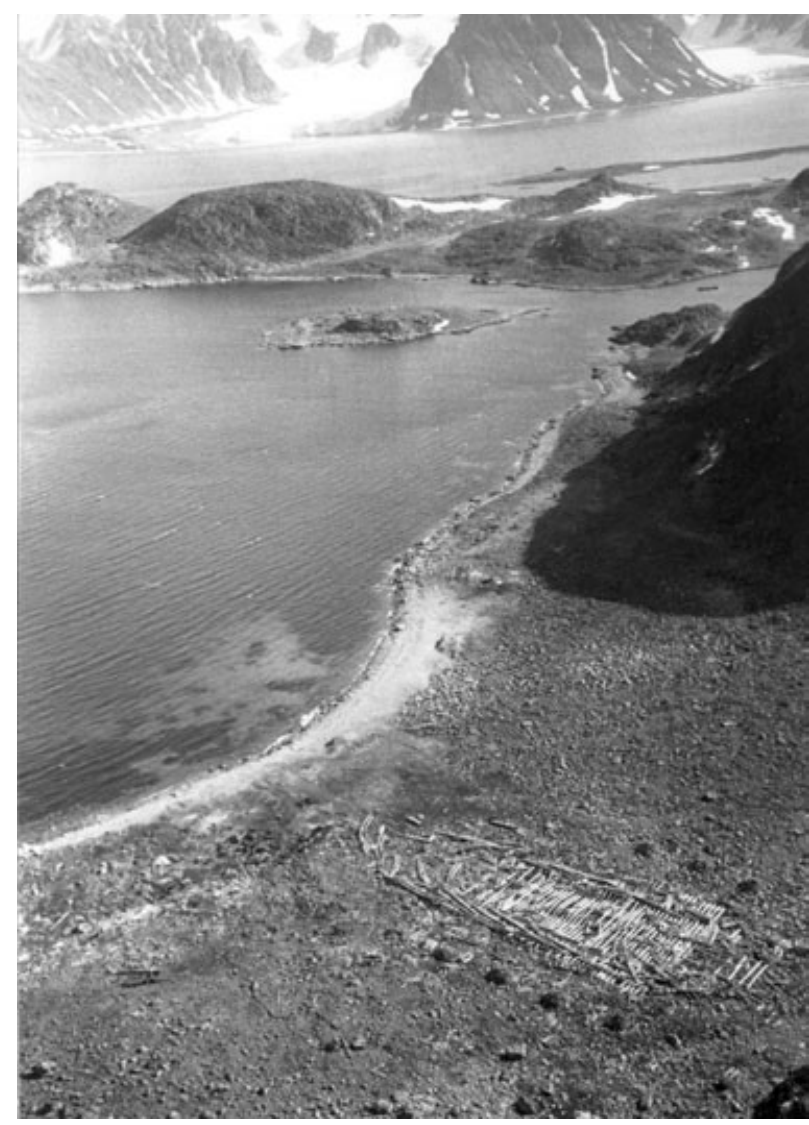

Figure 12 The remains of the airship hangar at Virgohamna, 1993. (Photo by P. J. Capelotti.)

sportsman" (Wellman 1911: 150). A photograph of this scene appears in a new account of Lerner's adventures (Lerner 2005: 117).

There were several German connections to the 1906 expedition. Liwentaal had tried and failed to purchase hydrogen in cylinders from Zeppelin, while the sulphuric acid for the manual production of hydrogen at Virgohamna was purchased from a firm called Reher amd Ramsden in Hamburg. But the strangest connection came when Wellman arrived at Virgohamna to find a green tent on the shore above which flew a German flag. Wellman was told that the occupant of the tent was a German journalist who claimed he knew the American. Wellman soon found himself reunited with an Otto von Gottberg, whom Wellman described "a famous correspondent representing the Berlin Lokal Anzeiger". It was Gottberg who had chartered the steamer Express under the command of Theodore Lerner.

Herr von Gottberg was at first very anxious lest I should not permit him to remain, having absorbed from American papers the false notion that we were working this Expedition as an advertising affair, and that therefore we might not wish the representatives of other newspapers to be present to get information. We quickly informed him of his error and of the fact that he was welcome to stay as long as he wished. (Wellman 1911: 150-151)

But Liwentaal later suggested a more sinister motive for Gottberg's visit. In 1917, Liwentaal wrote a series of sketches of Zeppelin, whose machines were at that time menacing England, for the London Sunday-Chronicle (Liwentaal 1917). Liwentaal claims that Gottberg, whom he names "Golberg", was in fact a retired officer who had been sent to Virgohamna by the German General Staff "to watch our proceedings". Liwentaal describes him as a very pleasant individual, fluent in six languages and wellsuited to his mission with one exception: "he took too much whisky".

Liwentaal writes of the fear the Germans felt at the potential of other nations to control "the empire of the air". Liwentaal admitted that he himself was slow to recognize German military ambition, but that the visit to Virgohamna in 1906 convinced him that Germany was serious in its intentions to expand German power in Europe, by force if necessary. When von Gottberg drank too much,

he was always insisting on the greatness of the German Empire. One day when I had treated his boastfulness somewhat lightly he broke out furiously: "Yes. We will make war when we think the moment has arrived. We shall over-run Belgium and jump on France unawares. We shall get to Paris in a fortnight, and settle France in a month. Then we shall take the French Navy and destroy Britain". (Liwentaal 1917)

In his account of the incident for the London SundayChronicle, Liwentaal relates that Wellman simply laughed at this. Liwentaal felt that an Englishman might have laughed at it as well in the summer of 1906. But Liwentaal had worked personally for Zeppelin. He felt sure that Gottberg's presence at Wellman's base camp was calculated to find more than a good story; rather, it was a mission to locate anything which might be used for the German war machine.

Liwentaal's suspicions might be supported by one of the images stored at the Norwegian Museum of Cultural History (Fig. 4), which seems to show several German officers examining Wellman's disassembled motor sledge at Virgohamna. Liwentaal further believed that Gottberg's reports on the Wellman expedition "apparently gave to the German staff the idea that our work required complementary investigations" (Liwentaal 1917). In this he was partly correct, since Zeppelin himself, along with the meteorologist Hergesell, would later investigate Svalbard as a base for airship operations. 


\section{Aftermath: war, lies and the Gulf Stream}

Wellman himself never mentioned the incident with von Gottberg in his exploring memoir, The aerial age, published 3 years prior to the start of the First World War. He does, however, end the book with a plea to the US government to develop a fleet of airships to serve as an aerial defense force for the coastlines of the American continent. Wellman's expeditionary airship, America, which failed so badly at Virgohamna in August 1906, was extensively modified by an itinerant aeronaut and photographer named Melvin Vaniman for another attempt on the pole from Virgohamna in 1907. Vaniman scrapped the original Louis Godard car and designed and built one of his own (Van Dyk 1996). Vaniman modified America yet again for a third try by airship in 1909. Wellman's two flights in the America in 1907 and 1909 marked the first time that a motorized airship had flown in the Arctic.

In July 1909, 1 month prior to Wellman's final attempt to reach the pole through the air, Zeppelin announced his own intention to reach the North Pole in an airship. This bold plan was curtailed by doubts about the infrastructure in Svalbard to handle such an expedition, by the American claims to the pole later that year and, soon, by preparations for aerial war in Europe. In September 1909, the American polar explorers Robert Peary and Frederick Cook both falsely claimed to have reached the North Pole-Cook in 1908 and Peary in 1909. This news discouraged not only Zeppelin, but also Wellman, who abandoned the camp at Virgohamna and turned his aeronautical ambitions instead to crossing the Atlantic Ocean.

In October 1910, Wellman built a new airship for an attempt to reach Europe from America by an airship voyage across the North Atlantic. Taking off from Atlantic City, New Jersey, Wellman flew in a huge arc past Cape Cod before north-east winds pushed the airship southwards. The expedition continued for several days and over $1600 \mathrm{~km}$-nearly the distance from Virgohamna to the North Pole and back-before engine trouble forced the merkelig mann and his crew to abandon ship not far from Bermuda. A passing steamer delivered Wellman and his crew back to shore. Before abandoning the airship, the crew punched holes in the large fuel tank, and Wellman thought that the airship must have sunk to the bottom of the Atlantic Ocean soon after. But Van Dyk uncovered two articles that might tell a different story. A New York Times article (21 May 1911) reported that on 21 December 1910, "officers of the Russian steamship Heros were of the opinion that they sighted the remains of the Wellman airship east of the Bahama Islands. They described the object as a long floating shape, high in the centre, and dropping off at the ends". If this sighting is accurate, America drifted south from Bermuda through- out October, still aloft, but gradually losing its lifting power, until finally settling into the ocean somewhere near the Bahamas in November or December.

Even more interesting, a report from the Times of London (22 May 1911) stated that a few days earlier, in clear weather, the White Star liner Celtic had passed what appeared to be the remains of an airship some $995 \mathrm{~km}$ west of Fastnet, the small island that is the southernmost point of the Republic of Ireland. This sighting would appear to corroborate the Russian sighting of December, and indicate that the airship America had in fact crossed the Atlantic, albeit as flotsam. If true, the wreck of America lies somewhere off the west coast of Ireland, the first aircraft to make the journey from the New World to the Old. That it accomplished this feat for the most part unmanned and underwater is somehow a fitting final tribute to the aeronautical career of its adventuring captain.

\section{Acknowledgements}

For kindly sharing the results of their research, the authors wish to thank the German polar guide Andreas Umbreit, as well as Neil Fulton and Jan Anders Diesen of the Department of Television and Film at Lillehammer University College. Additional thanks are due to Dr Susan Barr of Riksantikvaren in Oslo, and to Ms Jeannette Ullrich of the Penn State University Abington College Library.

\section{References}

Baldwin E.B. 2004. The Franz Josef Land Archipelago: E. B. Baldwin's journal of the Wellman Polar Expedition, 1898-1899. P.J. Capelotti (ed.). Jefferson, NC: McFarland.

Barr S. 1980. Virgohamns historie. Et øde, uhyggelig sted, en ukoselig bukt. (The history of Virgohamna. A desolate, eerie place, a dismal bay.) Svalbardposten 17-80/81, 6-7.

Binney G. 1925. With seaplane and sledge in the Arctic. London: Hutchinson \& Co.

Cailliez J.-C. 2004. Alexandre Liwentaal, pionnier suisse de l'aéronautique européenne. (Alexandre Liwentaal, Swiss pioneer in European aeronautics.) Geneva: Editor Secavia.

Capelotti P.J. 1994. A preliminary archaeological survey of Camp Wellman at Virgohamn, Danskøya, Svalbard. Polar Record 30, 265-276.

Capelotti P.J. 1997. The Wellman polar airship expeditions at Virgohamna, Danskoya, Svalbard; a study in aerospace archaeology. Meddelelser 145. Oslo: Norwegian Polar Institute.

Capelotti P.J. 1999a. By airship to the North Pole: an archaeology of human exploration. New Brunswick, NJ: Rutgers University Press.

Capelotti P.J. 1999b. Virgohamna and the archaeology of failure. In U. Wråkberg (ed.): Centennial of S.A. Andrée's 
North Pole Expedition. Proceedings of a conference on S.A. Andrée and the agenda for social science research of the polar regions. Bidrag till Kungliga Svenska Vetenskapsakademiens Historia 28, 37-52.

Capelotti P.J. 2006. E. B. Baldwin and the AmericanNorwegian discovery and exploration of Graham Bell Island, 1899. Polar Research 25, 155-171.

Diesen J.A. \& Fulton N. 2007. Wellman's 1906 polar expedition: the subject of numerous newspaper stories and one obscure film. Polar Research 26, 76-85.

Fiennes R. 2003. Captain Scott. London: Hodder \& Stoughton.

Lerner T. 2005. Polarfahrer: Im Banne der Arktis. (Polar traveller: spellbound by the Arctic.) F. Berger (ed.). Zurich: Oesch Verlag.

Liwentaal A. 1917. Germany's long preparations for war. London Sunday-Chronicle, 27 January.
Nansen F. 1920. En ferd til Spitsbergen. (A journey to Spitsbergen.) Kristiania: Jacob Dybwads Forlag.

New York Times 1906. Pole hunter's airship to be ready in May. 11 March, p. 7.

New York Times 1906. Will reach the pole by airship-Wellman. 24 April, p. 11.

Popular Mechanics 1906. Wellman Airship Expedition. Vol. 8, No. 7. Pp. 701-703.

Times of London 1911. A derelict airship. 22 May, p. 16a. Van Dyk H. 1996. The evolution of the Wellman/Vaniman airships. Parts 1-3. Jack Knight Air Log-The Zeppelin Collector, January, April, July.

Wellman W. 1898. Where is Andrée? McClure's Magazine 10, 422-426.

Wellman W. 1911. The aerial age. New York, NY: A.R. Keller. 